\title{
Erratum to: A Simple and Accurate Method to Measure Total Gaseous Mercury Concentrations in Unsaturated Soils
}

Christopher W. Moore • Mark S. Castro •

Steven B. Brooks

Published online: 6 April 2011

(C) Springer Science+Business Media B.V. 2011

Erratum to: Water Air Soil Pollut

DOI: $10.1007 / \mathbf{s} 11270-010-0691-7$

The original Figure 4 did not include the units.

The bottom axis of Figure 4 should read: TGM Concentration $\left(\mathrm{ng} \mathrm{m}^{-3}\right)$

The online version of the original article can be found at http:// dx.doi.org/10.1007/s11270-010-0691-7.

C. W. Moore $(\bowtie) \cdot$ M. S. Castro

Appalachian Laboratory,

University of Maryland Center for Environmental Science,

301 Braddock Road,

Frostburg, MD 21532, USA

e-mail: cmoore@umces.edu

S. B. Brooks

Atmospheric Turbulence and Diffusion Division,

NOAA Air Resources Laboratory,

Oak Ridge, TN, USA 